\title{
KARAKTER AGRONOMI BEBERAPA PADI LOKAL ACEH
}

\author{
Agricultural Characteristic Some Gogo Rice of Local Aceh \\ Mita Setyowati $^{1 *}$, Jekki Irawan $^{1}$, Leni Marlina ${ }^{2}$ \\ ${ }^{1)}$ Dosen Prodi Agronomi Fakultas Pertanian UTU, Meulaboh 23615 \\ ${ }^{2)}$ Mahasiswa Alumni Prodi Agroteknologi Fakultas Pertanian UTU \\ *Email : mitasetyowati@utu.ac.id
}

\begin{abstract}
This research aimed to identify the agronomy character of local rice genotype of Aceh as morphological characteristic. The research conducted at the Experimental Garden of Teuku Umar University, Meulaboh West Aceh from September 2016 to March 2017. The materials used in this research are 5 local accessions of local gogo rice of Aceh: Ramos, Dewi, Sigupai, Tinggong, Siputeh, and IR 64 as control. This research used observation method. The growth and production data were presented and analyzed in graphical form. The visual observation data was presented in the form of documentary photographs and described in descriptions. The results showed that the longest plant length at age 20 days after planting (HST), $40 \mathrm{HST}$, and $60 \mathrm{HST}$ was found in local accession compared to IR 64 varieties. The tillers per clums age of 20 HST were found in Siputeh local accession, while at age 40 HST and 60 HST local accessions were the least number of tillers compared to IR 64 varieties. Long panicle (Dewi), weight of pithy grain (Ramos) and percentage of pithy grain (Ramos), percentage of empty grain (Ramos), of all best variables are found in local accessions in comparison with IR 64 varieties. The flowering age, weight of 1000 grains, and the number of productive tillers at local accessions are lower than that of IR 64 varieties.
\end{abstract}

Keywords : Character of Agronomy, Gogo Rice, Local Aceh

\section{PENDAHULUAN}

Padi (Oryza sativa L.) merupakan tanaman pangan paling penting di negaranegara berkembang dan merupakan makanan pokok sebagian besar penduduk Indonesia sehingga menjadikan beras sebagai komoditas strategis. Seiring dengan meningkatnya jumlah penduduk maka konsumsi beras di Indonesia terus meningkat, berdasarkan hasil survei Sosial Ekonomi Nasional tahun 2013, konsumsi beras mencapai $85,154 \mathrm{~kg}$ perkapita. Berdasarkan data statistik Produksi padi sawah di Provinsi Aceh tahun 2014 sebesar 1,796,150 ton Gabah Kering Giling (GKG) mengalami penurunan produksi sebesar 141,740 ton (BPS 2015).

Pada saat ini di propinsi Aceh diperkirakan masih ada petani yang membudidayakan padi varietas lokal terutama pada daerah-daerah yang kurang adaptif terhadap varietas unggul nasional seperti di dataran tinggi Gayo, Kabupaten Benar Meriah, Kabupaten Pidie, Kabupaten Nagan Raya dan pada beberapa daerah tingkat dua lainnya. Konservasi sumber daya genetik yang masih ada pada saat ini merupakan usaha yang sangat diperlukan terhadap peningkatan 
produktifitas padi melalui penggunaan berbagai teknologi pada masa yang akan datang agar dapat dimanfaatkan dalam program pemuliaan (Bhuyan et al. 2007) dan dapat dijadikan sebagai dasar untuk pengajuan Perlindungan Varietas Tanaman (Menkumham 2000).

Aceh merupakan salah satu provinsi yang memiliki areal persawahan untuk budidaya padi yang cukup luas. Luas lahan sawah di Aceh adalah 300,808 Ha (BPS 2015). Ketersediaan air merupakan faktor penting dalam usaha peningkatan produksi tanaman padi (Bouman et al. 2007). Padi adalah komoditi yang sangat peka terhadap kekeringan (Fischer dan Fukai 2003).

Provinsi Aceh memiliki banyak sekali genotipe atau varietas padi lokal yang belum diketahui tingkat tolerannya terhadap kekeringan. Melalui kegiatan eksplorasi ke sentra-sentra produksi padi di daerah yang masyarakatnya masih menggunakan varietas lokal di seluruh wilayah Aceh telah berhasil dikumpulkan sebanyak 50 genotipe padi lokal Aceh, namun belum seluruh koleksi tersebut diketahui resistensinya terhadap cekaman kekeringan (Bakhtiar et al. 2009).

Kegiatan indentifikasi karakter agronomi plasma nutfah padi lokal Aceh masih belum banyak dilakukan. Oleh karena itu, penelitian sangat penting dalam upaya mendapatkan data penciri plasma nutfah secara maksimal melalui studi keragaman genetik dan identifikasi morfologi yang bermafaat untuk sumber genetik tanaman. Dengan dilakukan identifikasi karakter agronomi plasma nutfah terhadap padi Lokal, sehingga dalam upaya perlindungan terhadap kekayaan plasma nutfah kita bisa dilakukan secara maksimal, karakterisasi sumber daya genetik akan memberikan nilai tambah dalam memperkaya "gene pool" dengan keragaman baru dari varietas lokal tersebut untuk perakitan varietas baru (Neeraja et al. 2005).

Keragaman dan identitas padi merupakan bahan dasar untuk kegiatan pemuliaan dalam program perbaikan varietas. Dikebanyakan daerah, varietas modern yang berdaya hasil tinggi diadopsikan oleh petani dan budidaya dengan menggunakan varietas-varietas lokal menjadi sangat rendah. Selain itu, spesies-spesies liar juga terancam punah melalui perubahan penggunaan lahan, peningkatan areal pertanian yang menjadi areal marginal dan penebangan hutan (Jackson 1997).

Varietas padi merupakan salah satu teknologi utama yang mampu meningkatkan produktivitas padi dan pendapatan petani. Varietas padi juga merupakan teknologi yang paling mudah diadopsi petani karena teknologi ini murah dan penggunaannya sangat praktis (Badan Litbang Pertanian 2007). Penggunaan varietas dapat pengaruh besar terhadap tingkat produktivitas (Herawati 2012).

Keberadaan varietas lokal atau spesies liar sangat diperlukan sebagai sumberdaya genetik yang sangat diperlukan di dalam pemuliaan tanaman padi. Penggunaan sumberdaya genetik ini mempunyai dampak yang sangat besar terhadap peningkatan produktivitas tanaman ini pada berbagai negara. Sebagai salah satu contoh aksesi dari spesies liar Oryza nivera (IRGC 101508) yang digunakan untuk mengintroduksikan ketahanan terhadap virus kerdil rumput dari varietas budidaya. Varietas ini juga mempunyai lima belas varietas lokal dan keturunannya (Plucnet et al. 1987).

Kegiatan identifikasi merupakan kegiatan paling hulu dalam pengembangan pertanian dan menjadi ujung tombak dalam membantu memecahkan masalah yang dihadapi berkaitan dengan kegiatan pengembangan pada tahap selanjutnya. Kegiatan ini 
perlu dilakukan sedini mungkin untuk mengantisipasi atau meminimalisir kemungkinan punahnya plasma nutfah padi tersebut, terjadinya migrasi sumber daya genetik atau diadopsi (diokupasi) oleh negara lain. Menurut Harahap dan Silitonga (1989), kegiatan identifikasi penting untuk mendiskripsikan suatu tanaman.

Menurut Suhartini et al. (1991), potensi hasil pada tanaman padi yang dibentuk selama pertumbuhan sangat ditentukan oleh komponen hasil seperti jumlah gabah hampa per malai, jumlah malai dan bobot 1000 butir. Sedangkan menurut Rusdi dan Bahar (1999), tinggi tanaman, jumlah gabah per malai, gabah bernas, berat 1000 butir berkorelasi nyata dengan hasil gabah. Tanaman padi memiliki variasi yang tinggi. Terdapat beberapa aseksi plasma nutfah padi beras yang telah di koleksi dari berbagai lokasi padi di Indonesia.

Penelitian ini bertujuan untuk mengidentifikasi karakter agronomi genotipe padi lokal Aceh sebagai penciri morfologi.

\section{BAHAN DAN METODE PENELITIAN}

\section{Tempat dan Waktu}

Penelitian dilaksanakan di Kebun Percobaan Fakultas Pertanian Universitas Teuku Umar, Meulaboh Aceh Barat mulai dari tanggal 18 September 2016 sampai 20 Maret 2017.

\section{Bahan dan Alat}

Bahan-bahan yang digunakan dalam penelitian ini adalah 5 genotipe padi lokal Aceh (Ramos, Dewi, Sigupai, Tinggong, Siputeh) dan IR 64 sebagai pebanding, Pupuk organik, pupuk anorganik, dan pestisida. Sedangkan alat-alat yang digunakan adalah cangkul, parang, hand spayer, panplet nama, kamera digital, meteran, timbangan analitik, serta alat tulis menulis lainnya.

\section{Pelaksanaan Penelitian}

Sampel tanaman padi diperoleh dengan menanam tanaman padi aksesi Ramos, Dewi, Sigupai, Tinggong, Siputeh dan varietas IR64 sebagai pembanding. Pemberian sampel tanaman dapat dilihat pada Tabel 1.

Tabel 1. Susunan sampel tanaman

\begin{tabular}{ccc}
\hline No & Varietas & Jumlah Tanaman \\
\hline 1 & Ramos & 12 \\
\hline 2 & Dewi & 12 \\
\hline 3 & Sigupai & 12 \\
\hline 4 & Tinggong & 12 \\
\hline 5 & Siputeh & 12 \\
\hline 6 & IR 64 & 12 \\
\hline
\end{tabular}

\section{Perlakuan dan Penyemaian Benih}

Benih yang digunakan dalam penelitian ini adalah sebanyak $100 \mathrm{~g} /$ genotipe. Kemudian benih di rendam dengan larutan dithane 45 dengan konsentrasi 2 g/1 air selama 30 menit tujuannya untuk mencegah pertumbuhan jamur saat proses imbibisi. Setelah benih direndam kemudian benih tersebut dicuci dengan menggunakan air bersih sebanyak tiga kali berturut-turut. Selanjutnya benih direndam dengan air bersih selama 1 malam untuk proses imbibisi kemudian benih dikecambahkan selama 2 hari dengan cara dibalut dengan kain lembab. Setelah berkecambah benih tersebut dipindahkan ke baki persemaian yang telah disiapkan. Baki penyemaian yang digunakan adalah sebanyak 6 buah masing-masing berisi 1 genotipe. Baki yang digunakan berukuran $20 \mathrm{~cm}$ x $12 \mathrm{~cm}$, dan media penyemaian terdiri dari tanah aluvial dan pupuk kandang yang dimasukan dalam baki dengan perbandingan 2 : 1 ( 2 bagian tanah dan 1 bagian pupuk kandang).

Penyiraman pada penyemaian benih dilakukan pada pagi dan sore hari sesuaikan dengan keadaan dan cuaca sampai umur 15 hari. Bibit dipindahkan 
dalam media tanam pada umur 15 hari setelah semai (HSS).

\section{Persiapan Media Tanam}

Media tanam yang digunakan dalam penelitian ini adalah tanah yang diambil langsung di areal persawahan. Jenis tanah aluvial, tanah tersebut kemudian dimasukkan dalam pot dengan jumlah pot yang digunakan adalah 24 buah. Pot tersebut disusun sesuai dengan bagan percobaan seperti pada lampiran 1 dan dicampur dengan pupuk kandang dengan dosis $310 \mathrm{~g} /$ pot dan dilakukan pelumpuran.

\section{Pelumpuran Tanah}

Sebelum penanaman terlebih dahulu dilakukan pelumpuran tanah yang sudah dicampur dengan pupuk organik, pupuk organik diberikan 2 minggu sebelum tanam.

\section{Penanaman}

Penanaman dilakukan dengan 1 bibit setiap lubang. Dalam satu pot ditanam sebanyak 3 tanaman dengan jarak tanam $20 \mathrm{~cm} \times 20 \mathrm{~cm}$.

\section{Pemupukan}

Pemupukan dasar yang digunakan dalam penelitian ini adalah pupuk Urea, SP-36, dan $\mathrm{KCl}$ :

- Pemupukan I, umur 7 - 10 HST: 100 kg urea $(1.55 \mathrm{~g} / \mathrm{pot}),+100 \mathrm{~kg}$ SP 36 (1.55 g/pot), $+75 \mathrm{~kg} \mathrm{KCI}(1.16 \mathrm{~g} / \mathrm{pot})$.

- Pemupukan II, umur 21 - 28 HST: 100 $\mathrm{kg}$ urea $(1.55 \mathrm{~g} / \mathrm{pot})$.

- Pemupukan III, umur 35 - 40 HST: 100 kg urea $(1.55 \mathrm{~g} / \mathrm{pot}),+25 \mathrm{~kg} \mathrm{KCI}(0.388$ $\mathrm{g} / \mathrm{pot}$ ), pada saat tanaman menunjukkan fase primordia (pembentukan bakal bunga).

\section{Pemeliharaan}

Pemeliharaan meliputi pemberian air dilakukan sesuai dengan keadaan cuaca sampai tanaman berumur 60 HST. Penyulaman dilakukan pada 2 minggu setelah tanam (MST) dengan bibit yang sama, apabila tanaman ada yang mati. Penyiangan gulma dilakukan terhadap rumput-rumput yang tumbuh di sekitar tanaman padi dan di luar pot. Penyiangan rumput-rumput liar dengan cara mencabut menggunakan tangan. Pengendalian hama Walang Sangit dengan cara manual dan disemprot menggunakan sidabas dengan bahan aktif Biphenil Metil Carbamat (BPMC).

Panen

Panen dilakukan ketika gabah menunjukkan masak fisiologis atau 90-95 $\%$ padi telah menguning. Pemanenan dilakukan secara manual dan hasil panen masing-masing pot dihitung dengan keseluruhannya. Pemanenan dilakukan secara bertahap-tahap dikarenakan pemenenan tidak serentak.

\section{Pengamatan}

Parameter pengamatan dalam penelitian ini adalah pertumbuhan dan produksi sebagai berikut :

1. Panjang tanaman $(\mathrm{cm})$

Panjang tanaman diukur pada umur 20, 40 dan 60 HST dari pangkal batang sampai ujung daun terpanjang dengan menggunakan meteran.

2. Jumlah anakan perumpun (batang)

Jumlah anakan dihitung umur 20, 40 dan 60 Hari Setelah Tanam (HST).

3. Umur Berbunga (hari)

Pangamatan umur berbunga akan dihitung dari hari pertama semai sampai keluar malai sebanyak $80 \%$ dari populasi tanaman per satu percobaan.

4. Jumlah Anakan Produktif Per Rumpun (batang)

Pengamatan jumlah anakan produktif dilakukan pada saat panen dengan menghitung jumlah anakan produktif per rumpun.

5. Panjang malai $(\mathrm{cm})$

Panjang malai diukur mulai leher tanaman padi sampai ujung malai padi dengan menggunakan meteran. 
Pengukuran dilakukan satu hari sebelum panen.

6. Persentase gabah hampa (\%)

Presentase gabah hampa diamati setelah pengeringan. Dihitung persentase biji hampa per rumpun dengan rumus:

$\%$ Gabah hampa

$=\frac{\text { berat gabah hampa per rumpun }}{\text { berat gabah total per rumpun }} \times 100 \%$

7. Persentase gabah bernas (\%)

Presentase gabah bernas diamati setelah pengeringan. Dihitung persentase biji bernas per rumpun dengan rumus:

\% Gabah Bernas

$=\frac{\text { berat gabah bernas per rumpun }}{\text { berat total per rumpun }} \times 100 \%$

8. Bobot 1000 butir gabah (gram)

Pengamatan bobot 1000 butir gabah dilakukan dengan menimbang secara acak 1000 butir gabah kering. Dari setiap unit percobaan dengan cara ditimbang dalam satuan gram.

9. Berat gabah bernas per rumpun (gram)
Berat gabah bernas per rumpun diamati setelah pengeringan, di hitung per rumpun.

\section{Analisis Data}

Metode pengumpulan data pada penelitian ini adalah dengan metode observasi. Teknik ini dilakukan dengan menggunakan pengamatan langsung terhadap objek yang akan diteliti sehingga objek yang diteliti menjadi jelas.

Data pertumbuhan dan data produksi disajikan dan dianalisis dalam bentuk grafik. Data pengamatan visual disajikan dalam bentuk foto dokumentasi dan dijelaskan secara deskripsi.

\section{HASIL DAN PEMBAHASAN}

\section{Perbandingan Varietas}

Panjang Tanaman (cm)

Rata-rata panjang tanaman padi umur 20, 40, dan 60 HST pada beberapa aksesi lokal dan varietas dapat dilihat pada Gambar 1.

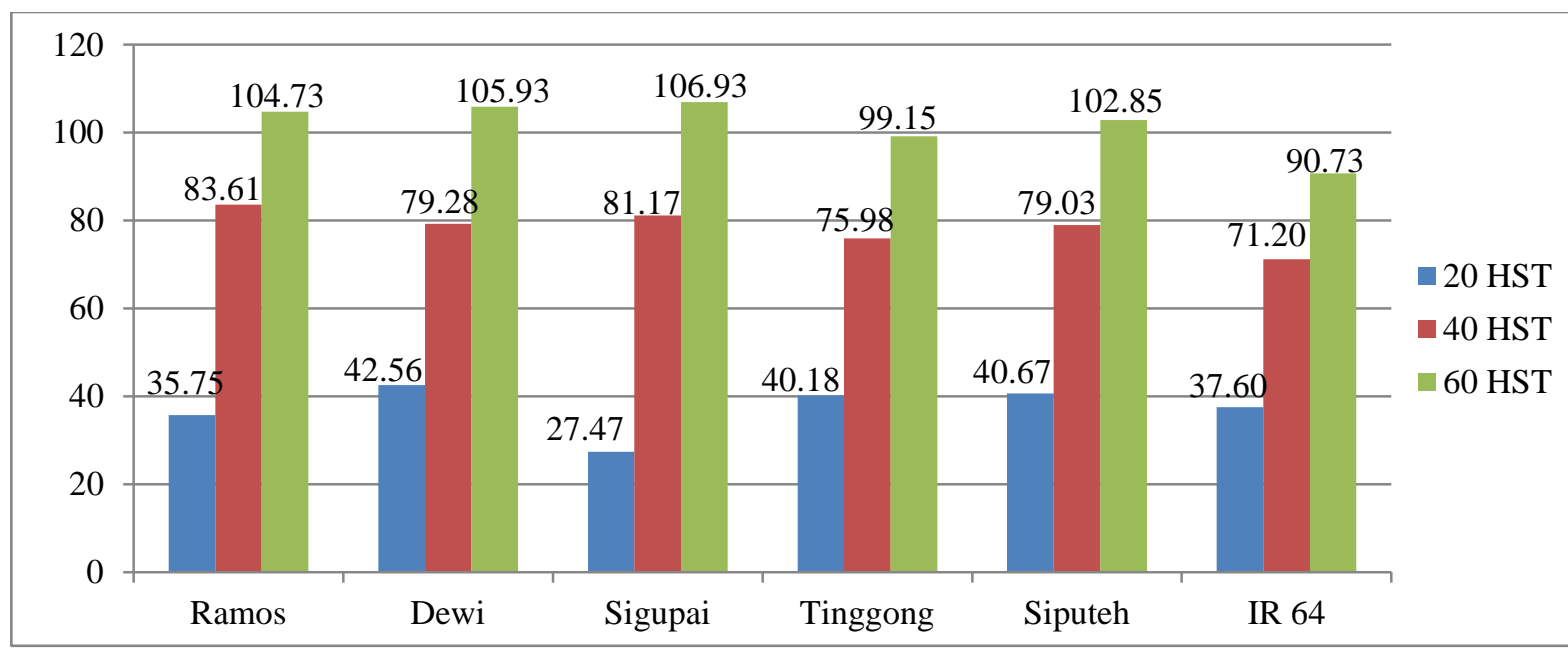

Gambar 1. Grafik panjang tanaman padi umur 20, 40, dan 60 HST pada beberapa aksesi lokal dan varietas

Gambar 1 menunjukkan bahwa dari semua umur tanaman pada umur 20 HST terpanjang terdapat pada aksesi Dewi (42.56) pada umur 40 HST terpanjang terdapat pada aksesi Ramos (83.61) sedangkan umur 60 HST panjang tanaman terpanjang dijumpai pada aksesi Sigupai (106.93) dibandingkan dengan varietas IR 64. 
Padi lokal Aceh memiliki karakter pertumbuhan yang tinggi dibandingkan varietar IR 64. Padi lokal tersebut sudah beradaptasi di lahan dan tahan terhadap hama dan penyakit tanaman. Padi lokal tersebut dapat dijadikan sumber genetik dalam perbanyakan varietas unggul baru. Liu et al (2007) menyatakan bahwa masing-masing varietas tersebut memiliki sifat dan karakteristik sendiri seperti panjang tanaman yang berbeda tingkat panjangnya yang dapat disilangkan antara varietas yang satu dengan varietas yang lainnya. Mildaerizanti, (2008) juga menambahkan bahwa perbedaan panjang tanaman lebih ditentukan oleh faktor genetik, selain itu dipengaruhi oleh kondisi lingkungan dimana tempat tanaman tersebut dibudidayakan.

Menurut IRRI (1996), kriteria panjang tanaman tergolong rendah adalah yang memiliki panjang tanaman $<110 \mathrm{~cm}$. Padi lokal Aceh pada penelitian ini memiliki panjang tanaman $>110 \mathrm{~cm}$ pada umur 60 HST, aksesi padi lokal yang diteliti memiliki umur lebih dari 60 HST sehingga panjang tanaman lebih dari 110 $\mathrm{cm}$ dibandingkan varietas IR 64.
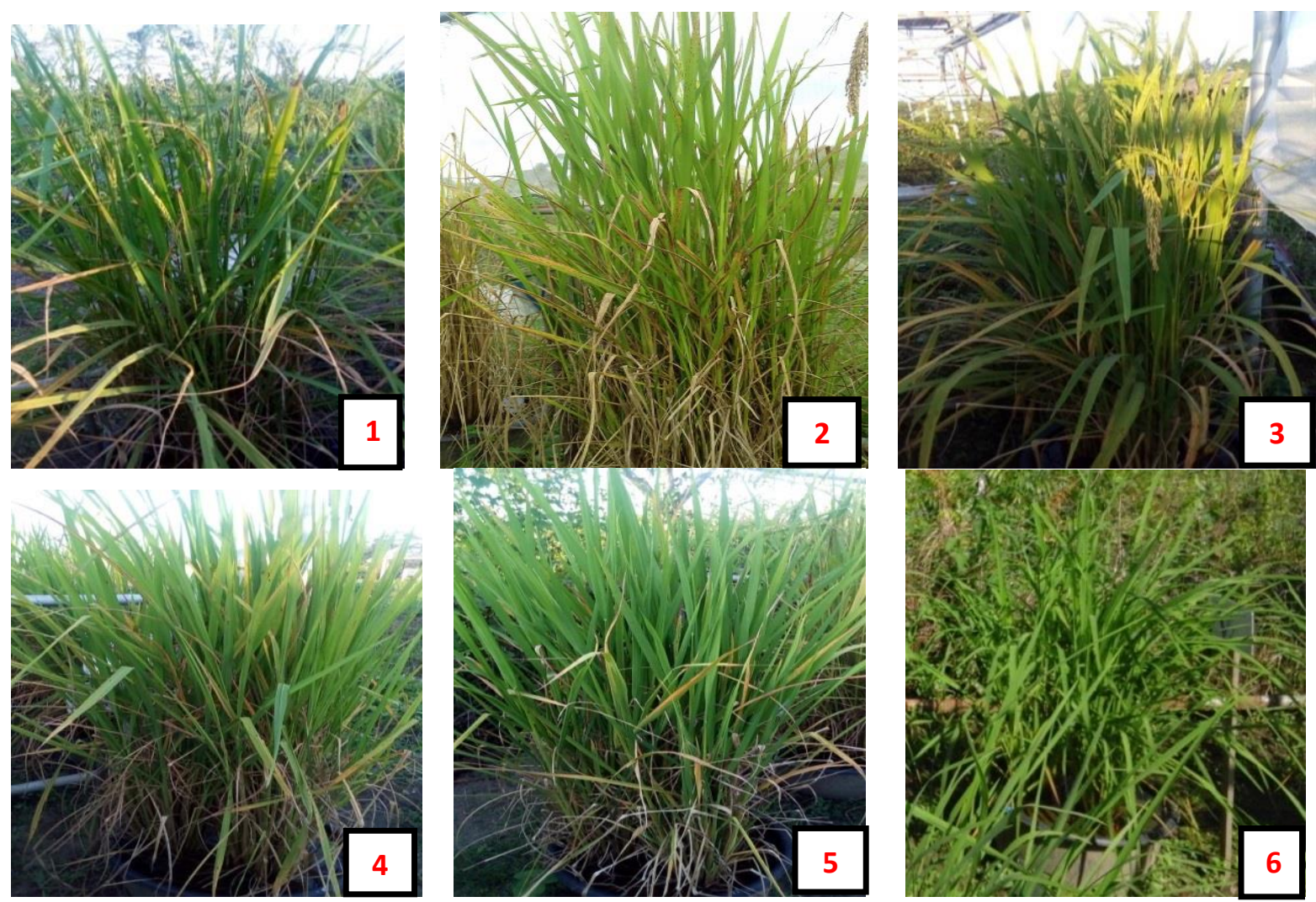

Gambar 2. Tanaman padi lokal aksesi Ramos (1), Dewi (2), Tinggong (4), Siputeh (5), pada umur 75 HST; Sigupai (3) umur 104 HST; varietas IR 64 (6) umur 40 HST

Jumlah Anakan Per Rumpun (Batang)

Rata-rata jumlah anakan per rumpun tanaman padi umur 20, 40, dan 60
HST pada beberapa aksesi lokal dan varietas dapat dilihat pada Gambar 3. 


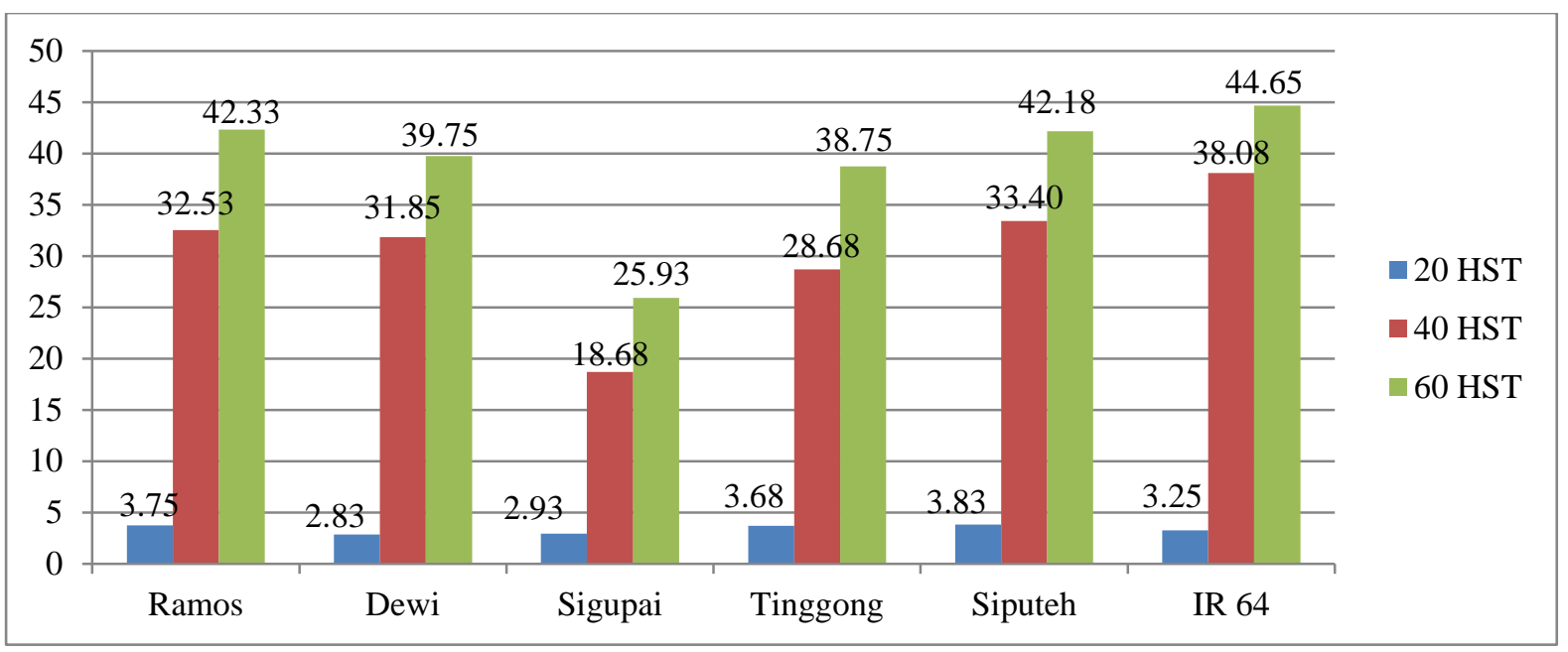

Gambar 3. Grafik jumlah anakan per rumpun tanaman padi umur 20, 40, dan 60 HST pada beberapa aksesi lokal dan varietas

Gambar 3 menunjukkan bahwa pada umur tanaman pada umur 20 HST jumlah anakan per rumpun terbanyak terdapat pada aksesi Siputeh dibandingkan dengan aksesi lokal lainya dan varietas IR 64. Sedangkan pada umur 40 HST dan 60 HST aksesi lokal memiliki anakan yang lebih rendah dibandingkan dengan varietas

Hal ini menunjukkan bahwa jumlah anakan sangat tergantung pada jarak tanam, musim tanam, serta penggunaan pupuk. Jarak tanam yang lebar, didukung lingkungan yang baik, akan menyebabkan bertambahnya jumlah anakan (AAK 1990). IR 64.
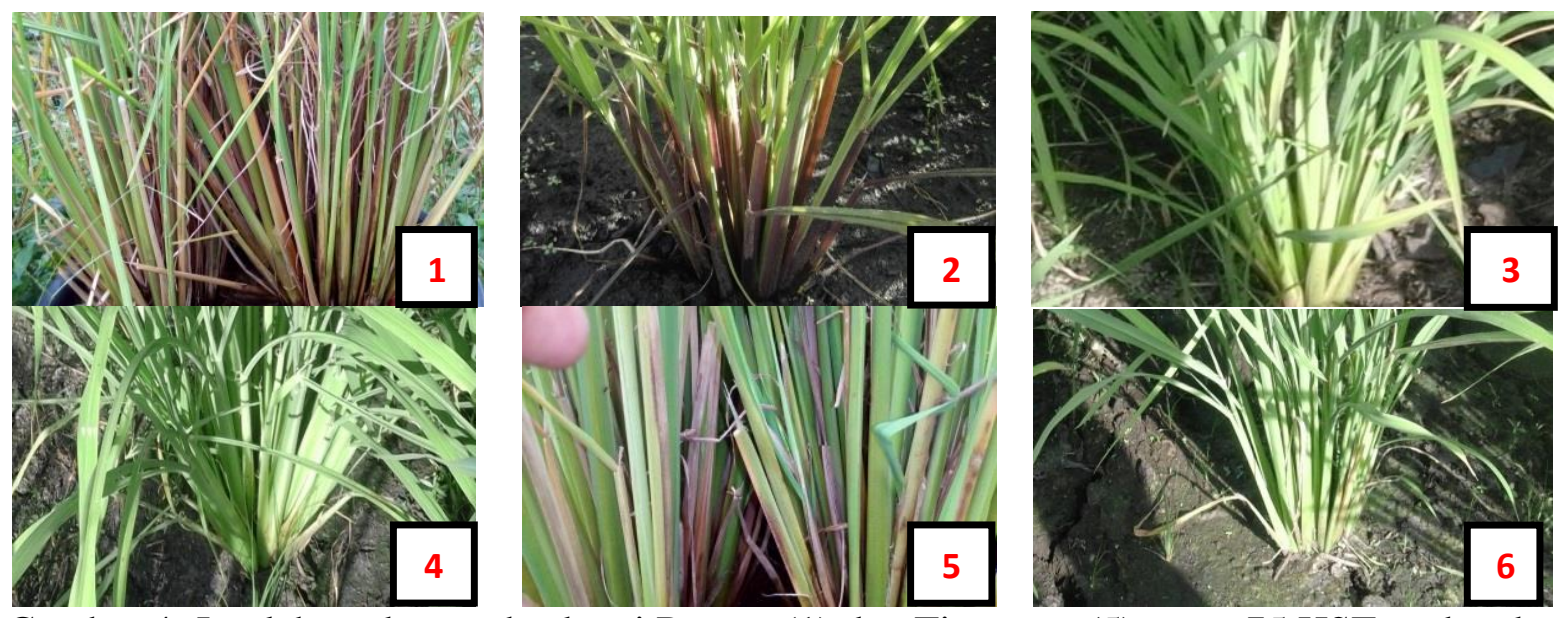

Gambar 4. Jumlah anakan pada aksesi Ramos (1) dan Tinggong (5) umur 75 HST, sedangkan Dewi (2), Sigupai (3), Siputeh (4) dan varietas IR 64 (6) umur 50 HST

\section{Gambar 4 menunjukkan Aksesi}

Dewi memiliki warna batang yang berwarna merah dibandingkan aksesi lain dan varietas IR 64.

\section{Umur Berbunga (hari)}

Rata-rata umur berbunga tanaman pada beberapa aksesi lokal dan varietas dapat dilihat pada Gambar 5. 


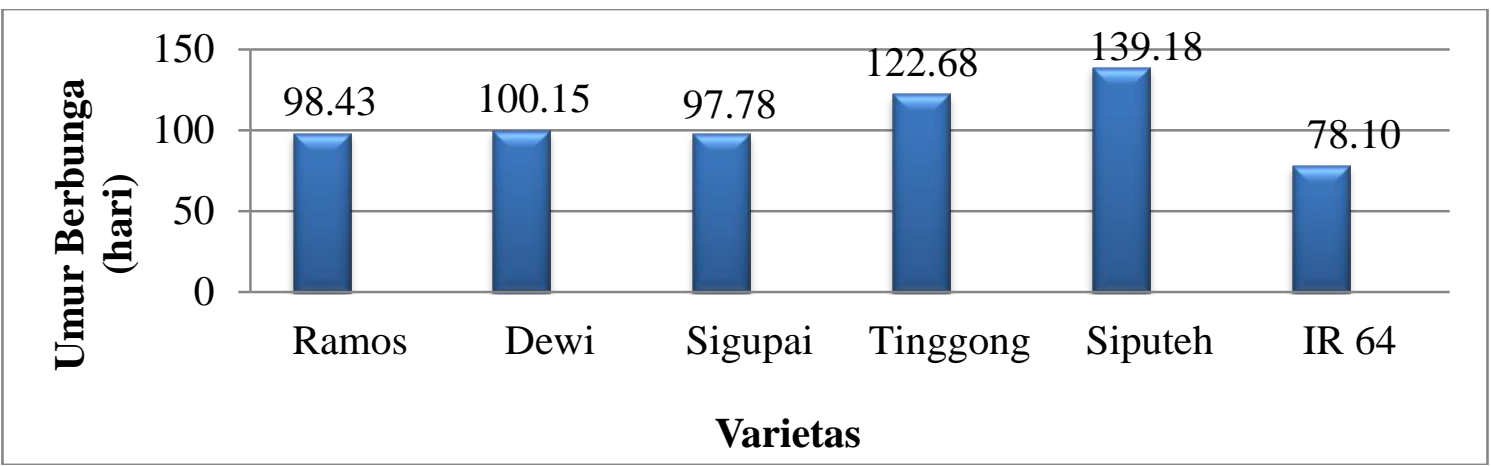

Gambar 5. Grafik umur berbunga tanaman pada beberapa aksesi lokal dan varietas

Gambar 5 menunjukkan bahwa umur berbunga tercepat terdapat pada tanaman padi varietas IR 64 yang berbeda tingkat kecepatan berbunga dengan aksesi lokal yang diujikan. Hal ini terkait dengan umur varietas IR 64 yang lebih pendek dibandingkan aksesi lokal. Menurut Epstein dalam Agustian (1994) yang menjelaskan bahwa tanaman yang berbeda varietas mempunyai pertumbuhan yang berbeda walaupun ditanam pada tanah yang berkondisi sama. Harjadi (1996) menambahkan bahwa setiap varietas selalu terdapat perbedaan respon genotip pada kondisi lingkungan tempat tumbuhnya. Umur berbunga juga dapat dipengaruhi oleh ketinggian tempat. Hasil penelitian Saidah et al. (2013) menunjukkan di dataran rendah (Kabupaten Sigi) padi kamba memiliki umur berbunga yang lebih cepat (90 HSS), dataran sedang 105 HSS, sedangkan dataran tinggi 120 HSS.
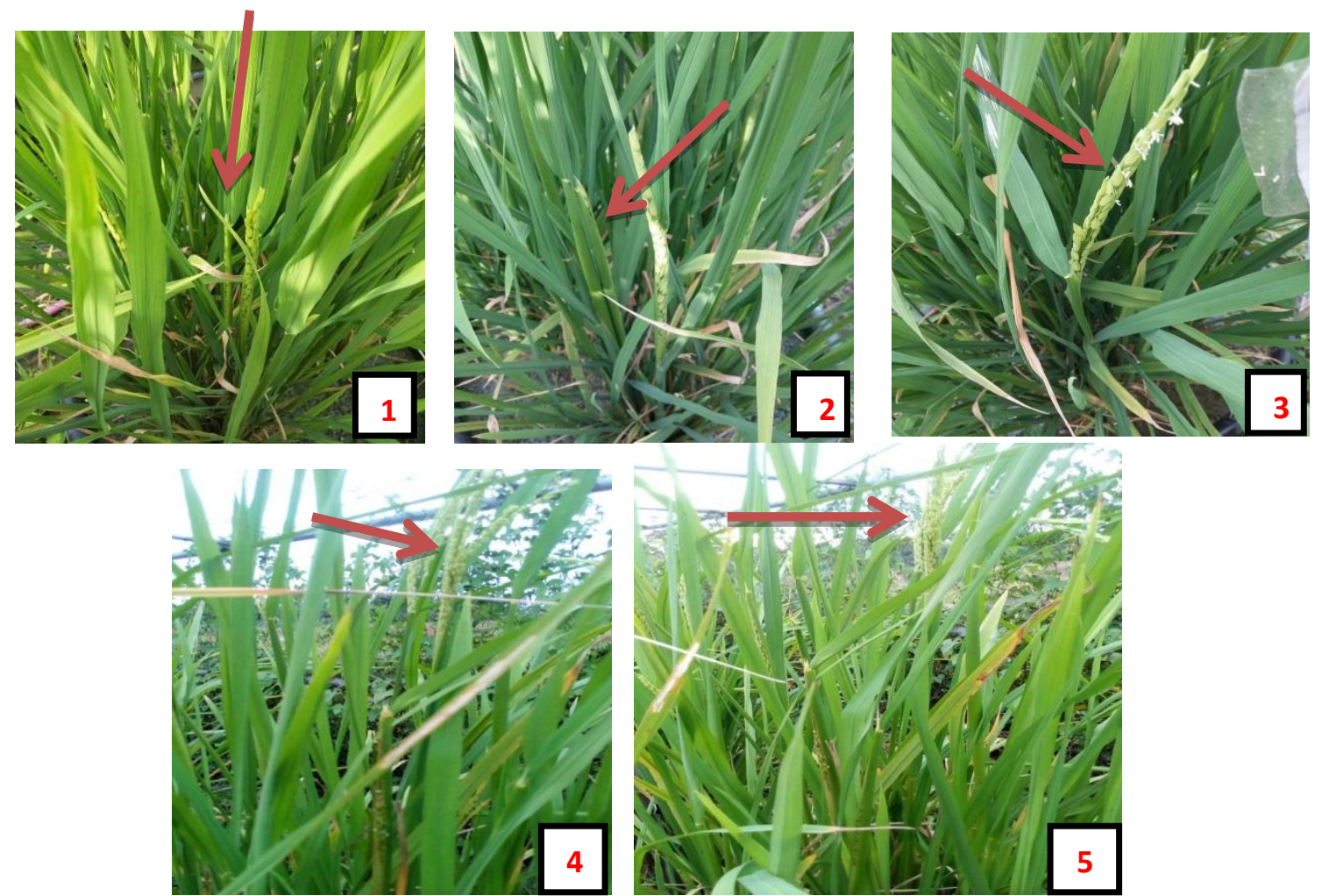

Gambar 6. Mulai keluarnya bunga varietas IR 64 (1) dan aksesi lokal Ramos (2), Sigupai (3), Siputeh (4), Dewi (5) 
Warna bunga Ramos berbeda dengan aksesi lain, Ramos memiliki ujung bunga berwarna kecoklatan hingga terbentuk buah, seperti ditampilkan pada buah fase masak susu pada gambar 7 .

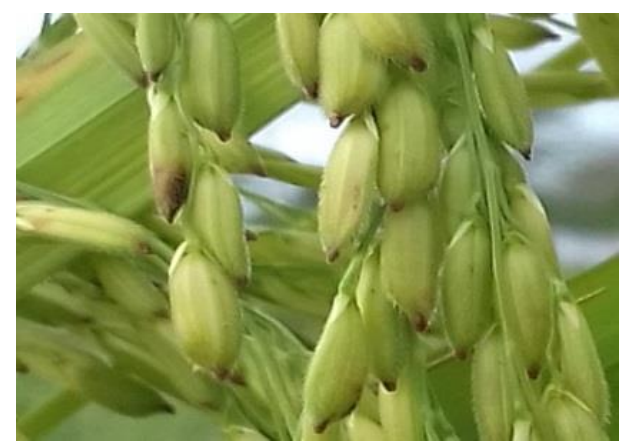

Gambar 7. Bunga aksesi Ramos pada fase masak susu

Jumlah Anakan Produktif Per Rumpun (batang)

Rata-rata anakan produktif per rumpun pada beberapa aksesi lokal dan varietas dapat dilihat pada Gambar 8.

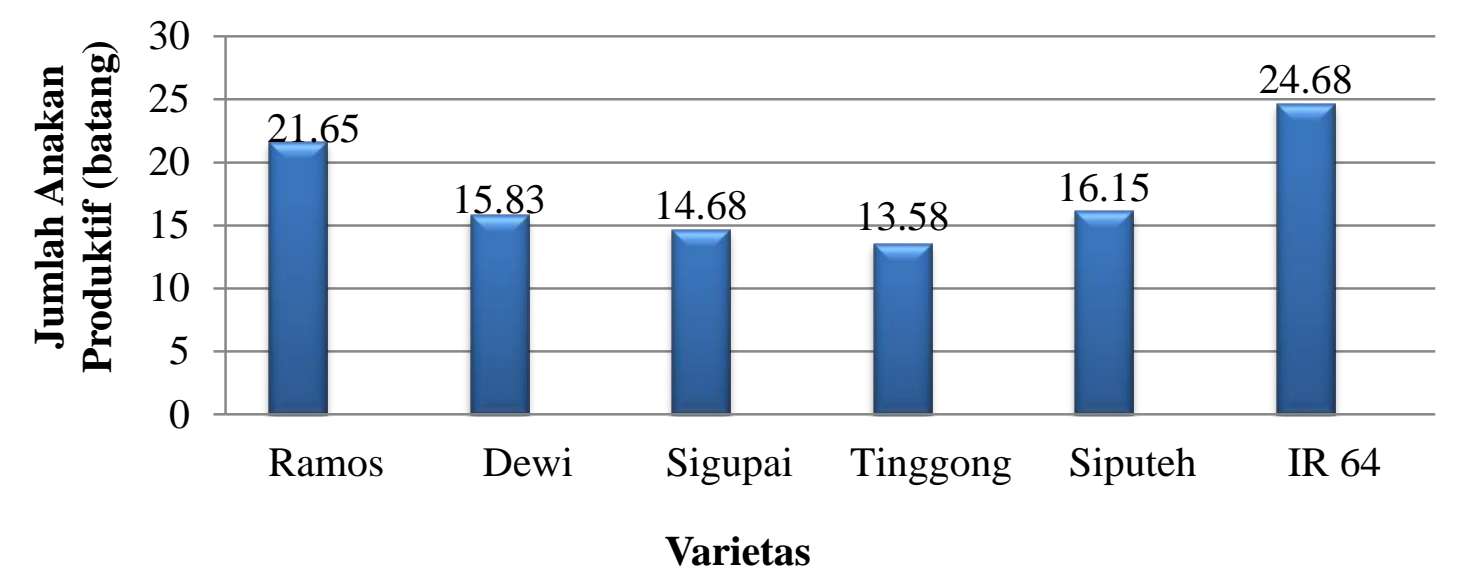

Gambar 8. Grafik jumlah anakan produktif per rumpun pada beberapa aksesi lokal dan varietas

Gambar 8 dapat dilihat jumlah anakan produktif pada aksesi lokal memiliki jumlah anakan produktif lebih sedikit dibandingkan dengan varietas IR 64. Hal ini disebabkan karena daya adaptasi lingkungan aksesi lokal lebih rendah dibandingkan varietas IR 64 yang memiliki adaptasi lingkungan lebih tinggi. Sesuai dengan pendapat Warda (2011) dalam Alavan et al. (2015) yang menyatakan bahwa jumlah anakan produktif sangat dipengaruhi aksesi dan galur yang memiliki adaptasi yang lebih baik terhadap lingkungan. Jumlah anakan padi jenis ini tergolong sedang sampai tinggi. Menurut IRRI (1996), kriteria jumlah anakan produktif tergolong sedang berkisar antara 5-9, sedangkan tinggi berkisar 10-19.

\section{Panjang Malai $(\mathrm{cm})$}

Rata-rata panjang malai pada beberapa aksesi lokal dan varietas dapat dilihat pada Gambar 9. 


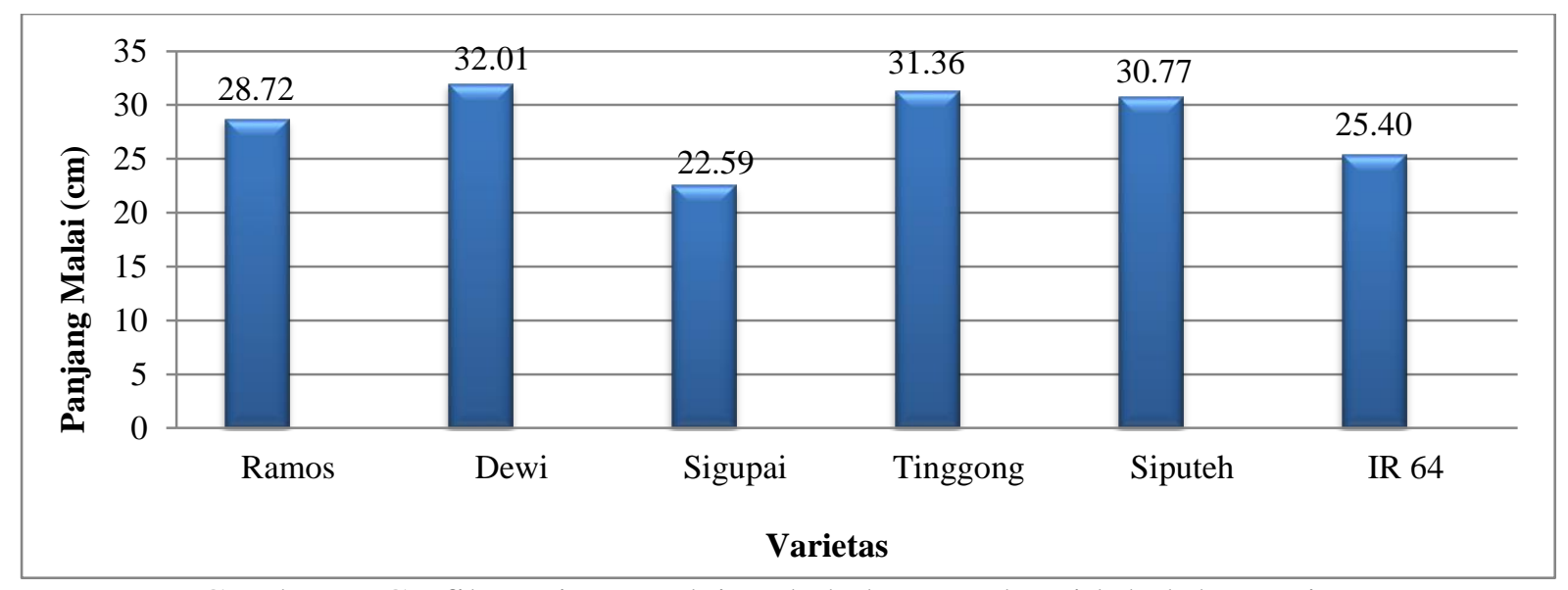

Gambar 9. Grafik panjang malai pada beberapa aksesi lokal dan varietas

Gambar 9 dapat dilihat panjang malai yang terpanjang terdapat pada aksesi Dewi dibandingkan dengan aksesi lokal lainnya dan varietas IR 64. Hal ini diduga aksesi dewi mempunyai potensi yang lebih tinggi dibandingkan dengan varietas IR 64 dan aksesi lokal lainnya. Sesuai dengan pendapat Abayawickrama et al. (2007)
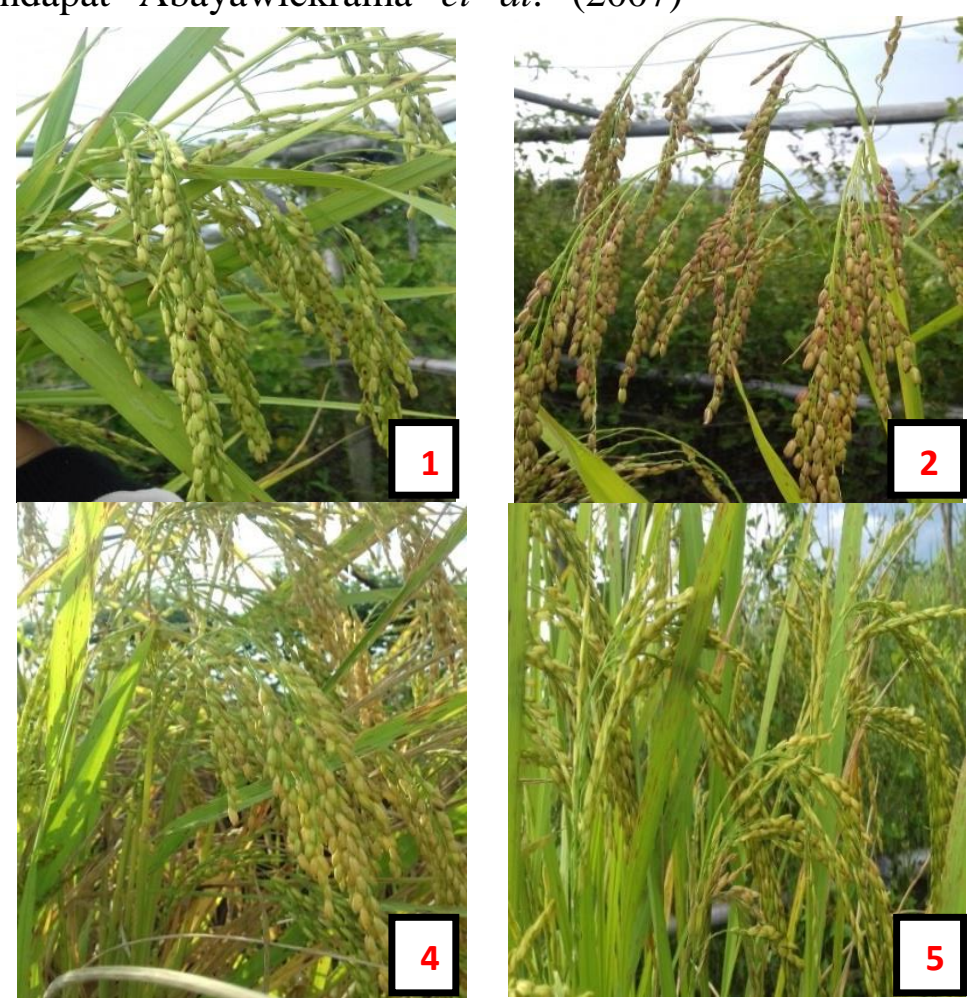

bahwa panjang malai yang produktif berkorelasi positif dengan hasil. Sependapat dengan AAK (1990), panjang malai dapat dibedakan menjadi tiga macam ukuran, yaitu malai pendek $(<20$ $\mathrm{cm})$, malai sedang $(20-30 \mathrm{~cm})$, dan malai panjang $(>30 \mathrm{~cm})$.

Gambar 10. Panjang malai pada beberapa aksesi lokal Ramos (1), Dewi (2), Sigupai (3), Siputeh (4), Tinggong (5) dan varietas IR 64 (6)

Gambar 10 menunjukkan bahwa terdapat perbedaan warna malai pada aksesi Dewi berwarna kemerahan, pada aksesi Tinggong berwarna hijau kekuningan dan pada aksesi Ramos berwarna coklat pada bagian ujung gabah. 
Berbeda dengan aksesi lain dan varietas IR pengisian bulir (gambar 11).

64, perubahan warna terjadi pada proses
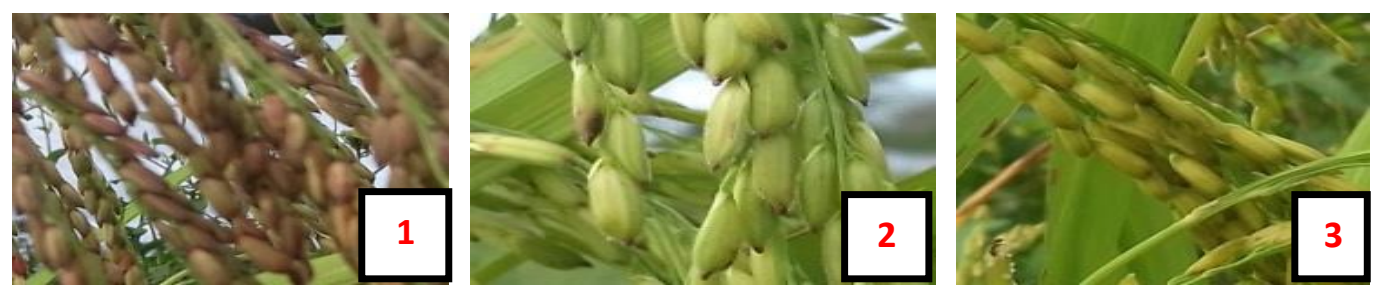

Gambar 11. Perbedaan warna buah fase masak susu pada aksesi Dewi (1), Ramos (2) dan Tinggong (3)

\section{Persentase Gabah Bernas (\%)}

Rata-rata persentase gabah bernaspada beberapa aksesi lokal dan varietas dapat dilihat pada Gambar 12.

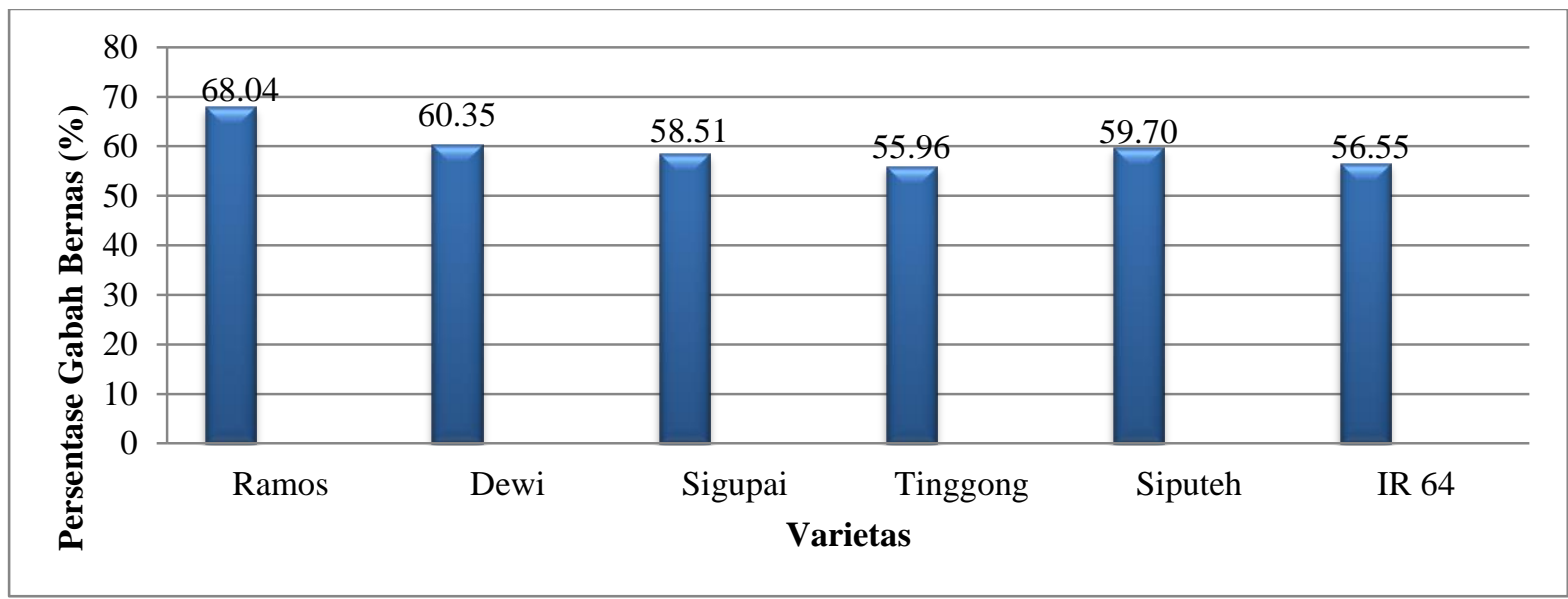

Gambar 12. Grafik persentase gabah bernas pada beberapa aksesi lokal dan varietas

Gambar 12 dapat dilihat persentase gabah bernas tertinggi terdapat pada aksesi Ramos dibandingkan dengan aksesi lokal lainnya dan varietas IR 64 yang digunakan. Hal ini menunjukkan bahwa aksesi padi lokal memiliki keunggulan genetik yang berbeda-beda terutama tingkat toleran terhadap cekaman lingkungan maupun tingkat proses absopsi unsur hara didalam tanah. Menurut AAK (1990) faktor lain yang menyebabkan jumlah gabah menurun adalah kelembaban, temperatur, asupan unsur $\mathrm{N}$ pada saat bunting serta hama dan penyakit. Hal ini sejalan dengan yang dikemukakan oleh Malia (2007), berkurangnya penggunaan aksesi padi lokal merupakan akibat dari introduksi bibit padi unggul yang cenderung memiliki umur tanam yang relatif cepat dan tahan hama, sehingga sebagian masyarakat menganggap bertanam padi unggul lebih menguntungkan. 

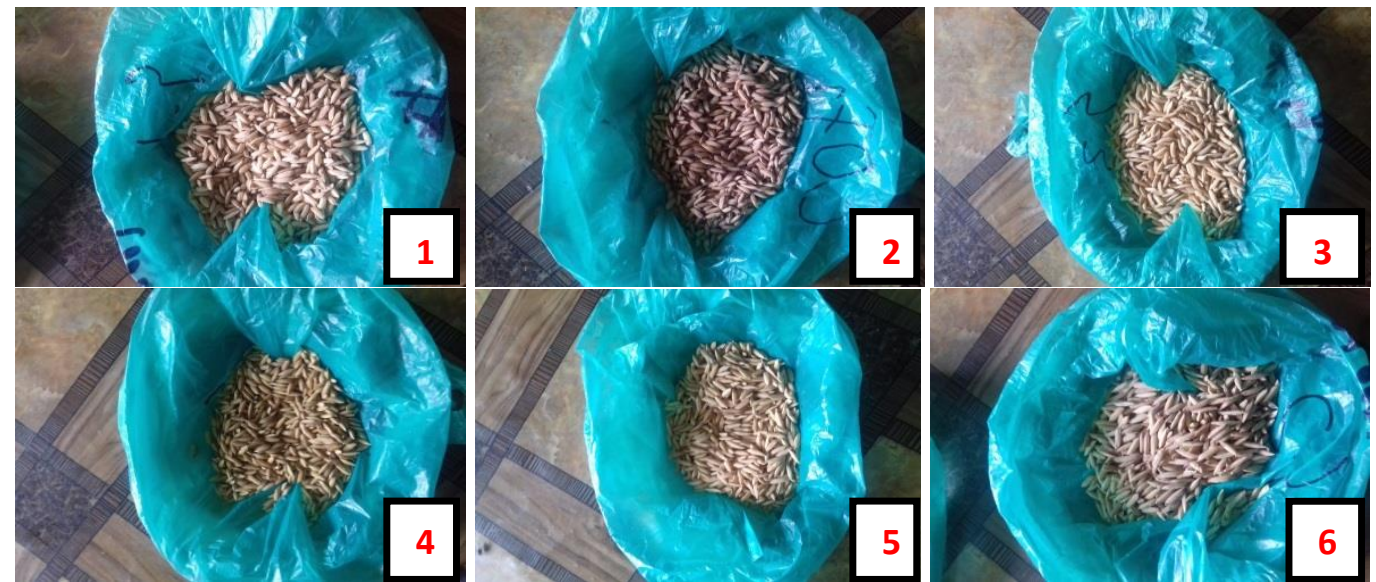

Gambar 13. Persentase Gabah Bernas aksesi lokal Ramos (1), Dewi (2), Sigupai (3), Tinggong (4), Siputeh (5) dan varietas IR 64 (6)

Gambar 13 menunjukkan bahwa terdapat perubahan warna dari fase masak susu ke masak biji, pada aksesi Dewi mengalami perubahan warna dari merah menjadi kuning bergaris ungu aksesi Tinggong mengalami perubahan warna dari hijau kekuningan menjadi kuning keemasan aksesi Ramos dari warna hijau menjadi kuning jerami bergaris coklat dengan ujung tetap berwarna coklat. Aksesi lokal yang lain mengalami perubahan warna dari hijau menjadi kuning jerami.

\section{Persentase Gabah Hampa (\%)}

Rata-rata persentase gabah hampa pada beberapa aksesi lokal dan varietas dapat dilihat pada Gambar 14.

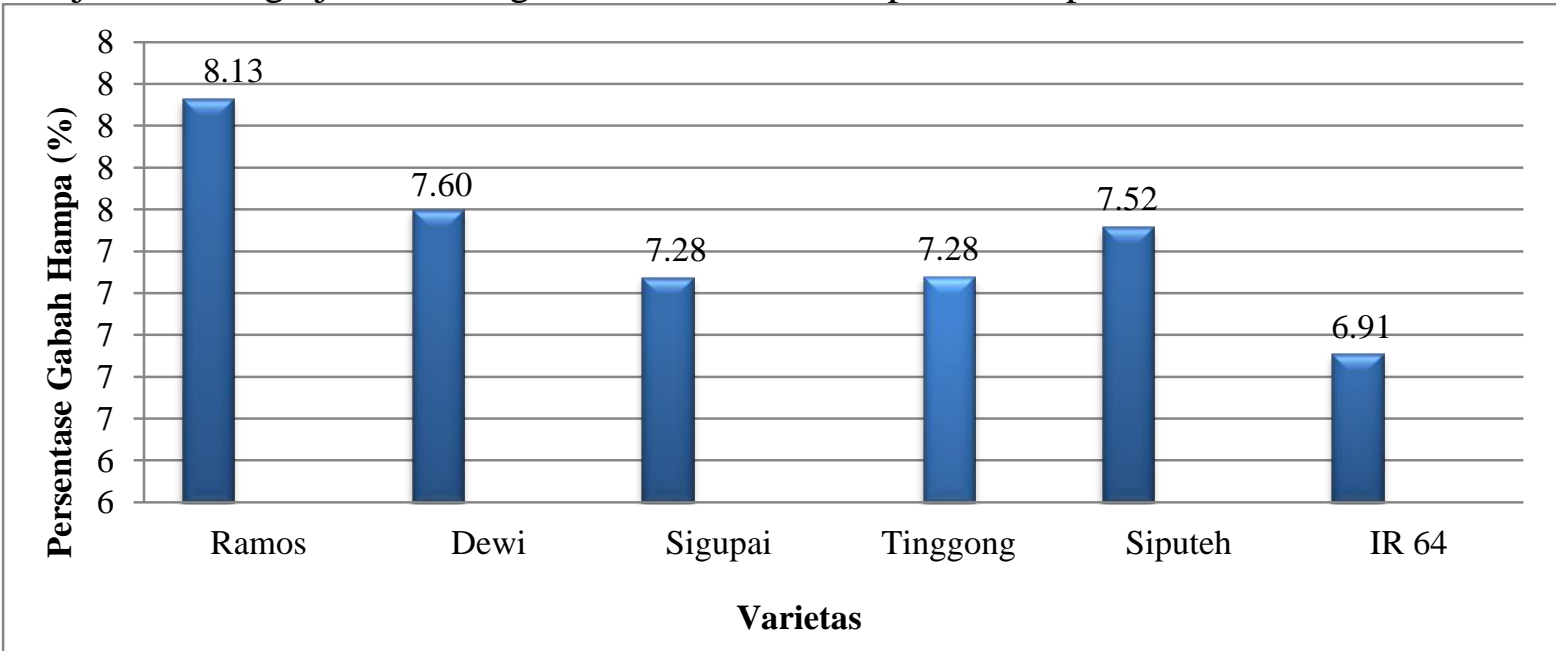

Gambar 14. Grafik Persentase gabah hampapada beberapa aksesi lokal dan varietas

Gambar 14 persentase gabah hampa tertinggi terdapat pada aksesi Ramos dibandingkan dengan aksesi lokal lainnya dan varietas IR 64. Hal ini diduga aksesi lokal memiliki penyerapan cahaya yang berkurang sehingga proses fotosintesi saat berlangsung terhambat pada saat penyerbukan terjadi dan jumlah batang yang rendah serta penyerangan hama pada tanaman. Sesuai dengan pendapat Raja
(1997) bahwa terjadinya gabah hampa bisa juga disebabkan oleh serangan walang sangit yang menghisap buah saat fase pengisian gabah.

\section{Berat Bobot 1000 Butir Gabah (gram)}

Rata-rata berat bobot 1000 butir gabah pada beberapa aksesi lokal varietas dapat dilihat pada Gambar 15. 


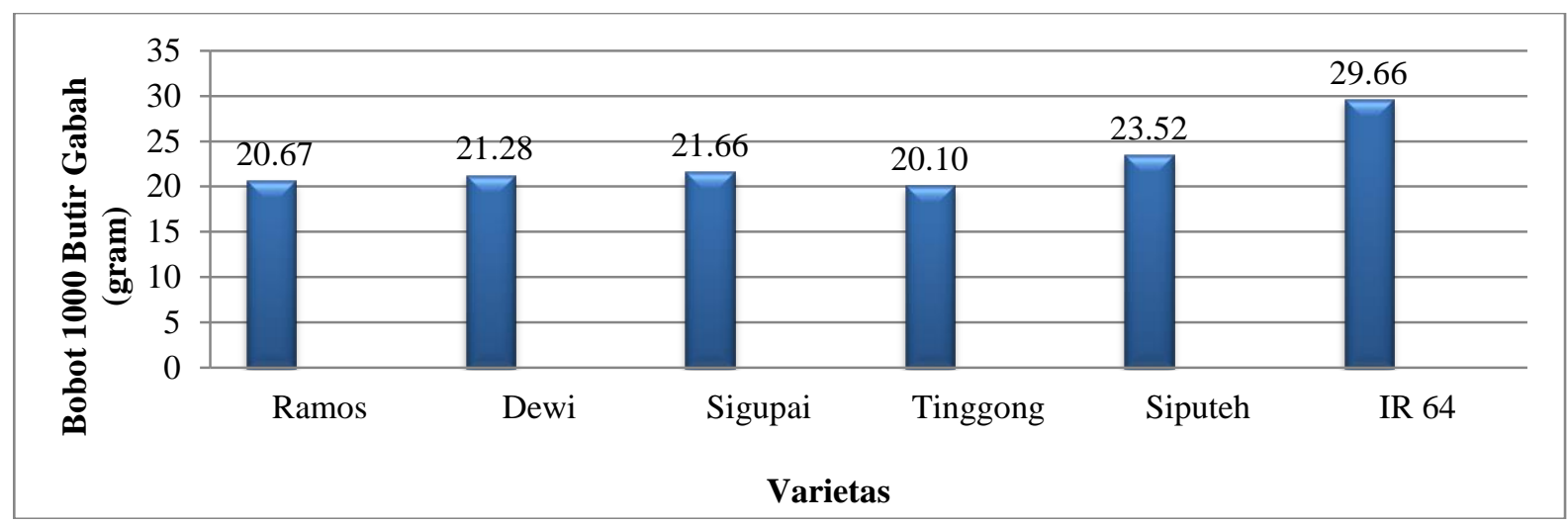

Gambar 15. Grafik Berat bobot 1000 butir gabah pada beberapa aksesi lokal dan varietas

Gambar 15 menunjukkan bahwa berat bobot 1000 aksesi lokal memiliki bobot yang lebih rendah dibandingkan veietas IR 64. Hal ini diduga karena besar kecilnya ukuran butir dapat menaikkan berat pada 1000 bitir gabah. Sesuai dengan pendapat Rafaralahly (2002) menyatakan bahwa berat 1000 butir gabah biasanya merupakan ciri yang stabil dari suatu aksesi, besarnya butir juga ditentukan oleh ukuran kulit, berat 1000 butir gabah bernas ditentukan oleh ukuran butir, namun ukuran butir itu sendiri sudah ditentukan selama malai keluar, sehingga perkembangan dalam mengisi butir sesuai dengan ukuran butir yang telah ditentukan dan bobot 1000 butir gabah bernas juga menggambarkan kualitas dan ukuran biji tergantung pada hasil yang bisa disimpan.

\section{Berat Gabah Bernas Per Rumpun (gram)}

Rata-rata berat gabah bernas per rumpun pada beberapa aksesi lokal varietas dapat dilihat pada Gambar 16.

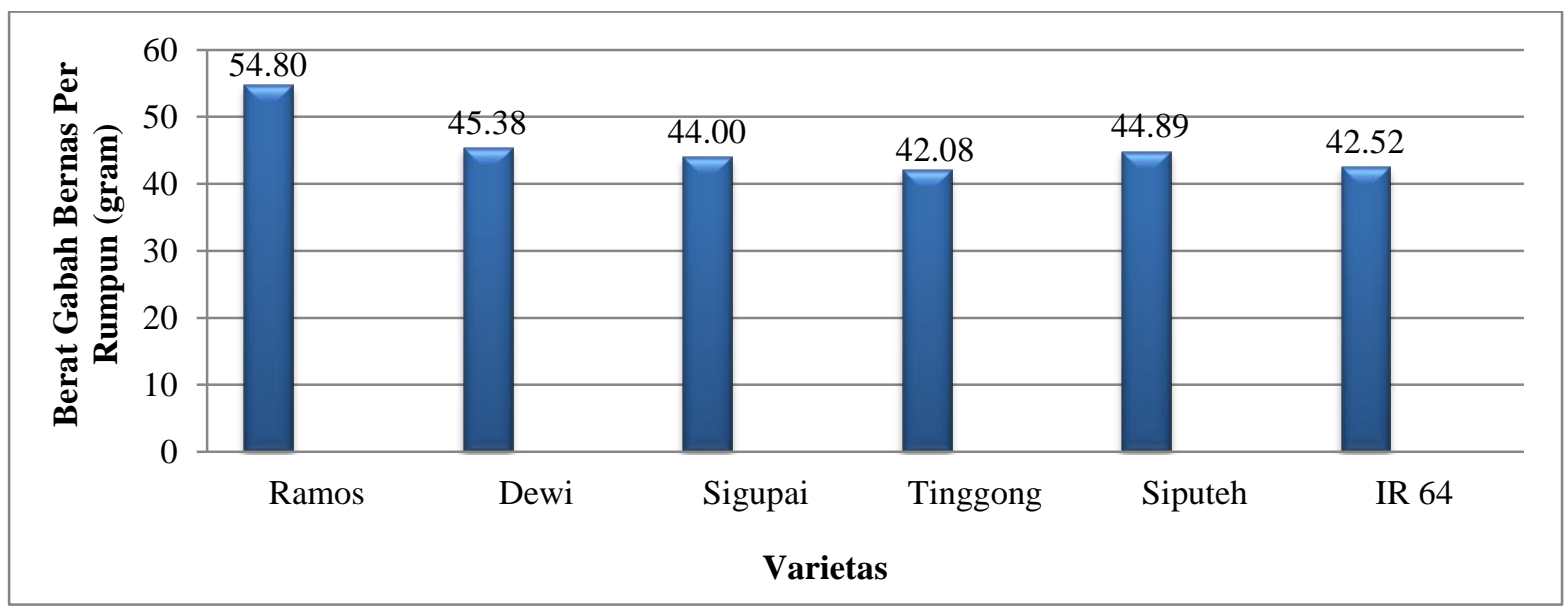

Gambar 16. Berat gabah bernas per rumpun pada beberapa aksesi lokal dan varietas

Gambar 16 menunjukkan bahwa berat gabah bernas per rumpun tertinggi terdapat pada aksesi lokal Ramos dibandingkan dengan aksesi lain dan varietas IR 64. Hal ini duga bahwa suhu lingkungan dan faktor genetik sangat mempengaruhi saat pengisian gabah.
Sesuai dengan pendapat Wirnas et al. (2006) melaporkan bahwa karakter jumlah gabah bernas dan jumlah gabah sangat dipengaruhi oleh faktor genetik. Suhu rata-rata lingkungan merupakan faktor pembatas juga dalam berbagai proses pembentukan dan perkembangan bulir 
padi, seperti pengisian bulir dan laju produksi bahan kering (Wang et al. 2006).

\section{KESIMPULAN}

Kesimpulan dari penelitian ini adalah panjang tanaman terpanjang pada umur 20 hari setelah tanam (HST), 40 HST, dan 60 HST terdapat pada aksesi lokal dibandingkan dengan varietas IR 64 . Anakan per rumpun terbanyak umur 20 HST dijumpai pada aksesi lokal Siputeh, sedangkan pada umur 40 HST dan 60 HST aksesi lokal terdapat jumlah anakan paling sedikit dibandingkan dengan varietas IR 64. Panjang malai ( Dewi), berat gabah bernas per rumpun (Ramos) dan persentase gabah bernas (Ramos), persentase gabah hampa (Ramos), dari semua peubah terbaik dijumpai pada aksesi lokal di bandingkan dengan varietas IR 64 . Sedangan data umur berbunga, bobot 1000 butir, dan jumlah anakan produktif pada aksesi lokal lebih rendah dibandingkan dengan varietas IR 64.

\section{DAFTAR PUSTAKA}

AAK. 1990. Budidaya Tanaman Padi. Jakarta (ID): Kanisius

Alavan A, Hayati R, Hayati E. 2015. Pengaruh pemupukan terhadap pertumbuhan beberapa varietas padi gogo (Oryza sativa L.). Jurnal Floratek. 10(1): 61-68

Abayawickrama ASMT, Fahim M, Abeysiriwardena DSDeZ, Madhusani KC, Dharmaratne RM. 2007. Contribution of yield related characters to grain yield improvement ini different age groups of rice (abstrak). News and Events of the Departement of Agriculture, Agriculture News in Sri Lanka. [internet]. [diunduh 2017 Jan 09]. Tersedia pada: http://sgridept.gov.lk/NEWS/asda.h $\mathrm{tm}=\mathrm{con}$
Agustian. 1994. Pengaruh pemberian kombinasi fosfat dengan kalium terhadap pertumbuhan dalam hasil dua varietas kacang tanah (Arachis hypogea L.) [skripsi]. Darussalam Banda Aceh (ID): Universitas Syiah Kuala

Badan Litbang Pertanian. 2007. Pedoman Umum Produksi Benih Sumber Padi. Jakarta (ID): Badan Litbang Pertanian, Departemen Pertanian

Badan Pusat Statistik. 2015. Data Produksi Padi, Jagung, dan Kedelai Provinsi Lampung Tahun 2014. Lampung (ID): Berita Resmi Statistik

Bachtiar G, Surjokusumo S, Hadi YS, Nugroho N. 2009. Aplikasi buluh bambu untuk konstruksi rangka batang ruang. Jurnal Ilmu dan Teknologi Kayu Tropis. Vol. 7 (1): 22-26

Bhuyan N, Basanta N, Borah K and Sarma RN. 2007. Genetic diversity analysis in traditional lowland rice (Oryza sativa L.) of Assam using RAPD and ISSR markers. Current Science. 93 (7): 967- 972

Fischer KS and Fukai. 2003. How Rice Responds to Drought, p. 32-36. In: K.S. Fischer, R. Lafitte, S. Fukai, G. Altin and B. Hardy (Eds.). Breeding Rice For Drought-Prone Environments. Manila: International Rice Research Institute

Harjadi MMS. 1996. Pengantar Agronomi. Jakarta (ID): Gramedia Pustaka Utama

Harahap dan Silitonga. 1989. Perbaikan Varietas Padi Buku Kedua. Bogor (ID): Pusat Penelitian dan Pengembangan Tanaman Pangan

Harahap Z, Ampong Nyarko K, Olela JC. 1993. Striga hermonthica resistance in upland rice. Crop Prot. 12:229231 
Herawati WD. 2012. Budi Daya Padi. Yogyakarta(ID): Javalitera

IRRI. 1996. Standard Evaluation System for Rice. Los Banos-Philippines: International Rice Research Institute

Jackson MT. 1997. Conservation of rice genetic resources: the role of the International Rice Genebank at IRRI. Plant Molecular Biology 35: 61-67.

Liu QL, Xu XH, Ren XL, Fu HW, Wu DX, Shu QY. 2007. Generation and characterization of low phytic acid germplasm in rice (Oryza sativa L.). Theor Appl Genet. 114:803814

Mildaerizanti. 2008. Keragaan Beberapa Varietas Padi Gogo Di Daerah Aliran Sungai Batanghari. http://katalog.pustakadeptan.go.id/ $\sim$ jambi/getfile2php?src=2008/pros5 3f. pdf\&format=application/pdf

Menkumham Menteri Hukum dan Hak Asasi Manusia Republik Indonesia 2000. Undang-Undang Republik Indonesia Nomor 29 Tahun 2000 Tentang Perlindungan Varietas Tanaman

Neeraja CN, Hariprasad AS, Malathi S and Siddiq EA. 2005. Characterization of tall landraces of rice (Oryza sativa L.) using gene-derived simple sequence repeats. Current Science. 88 (1): 149-152

Plucknett DL, Smith NJH, Williams JT, Murthi AN. 1987. Gene Banks and the World's Food. Princeton: Princeton University Press

Rafaralahy S. 2002. An NGO Perspective on SRI and Its Origins in Madagascar. Assessments of The System of Rice Intensification (SRI): Proceeding of an
International Conference held in Sanya, China, April 1-4 2002. Ithaca NY: Cornell International Institute for Food, Agriculture and Development.

Raja B. 1997. Pertanian berkelanjutan di la han gambut. Jurnal Alami. 2(1): 1720

Rusdi E, H. Bahar. 1999. Kontribusi Karakter Agronomi dan Komponen Hasil terhadap Perbaikan Padi Sawah Dataran Tinggi. Jurnal Stigma. 7 (I): 16-20

Saidah, Sakka S, Arbit, Yusuf R. 2013. Laporan Hasil Kegiatan Uji Adaptasi Padi Lokal Kamba di Sulawesi Tengah. Palu(ID): UPTD Balai Sertifikasi Benih Tanaman Pangan dan Hortikultura Sulawesi Tengah

Suhartini T, Suwarno, Lubis, Sismiyati, Alidawati. 1991. Seleksi Galur untuk lahan Pasang Surut Sulfat Masam dan Gambut. Jakarta (ID): Badan Litbang Pertanian.

Wang YW, Zhai PM, Tian H. 2006. Extreme high temperatures in southern China in 2003 under the background of climate change. Meteorol Mon. 32(10):27-33

Warda. 2011. Keragaan Beberapa Varietas Unggul Padi di Kabupaten Bantaeng Sulawesi Selatan. Sulawesi Selatan: Seminar Nasional Serealia, Balai Pengkajian Teknologi Pertanian Sulawesi Selatan.

Wirnas D, I Widodo, Sobir, Trikoesoemaningtyas, D Sopandie. 2006. Pemilihan karakter seleksi untuk menyusun indeks seleksi pada 11 populasi kedelai generasi F6. Bul. Agron. 34:19-24 